\title{
The Disease Ecology, Epidemiology, Clinical Manifestations, and Management of Emerging Cryptococcus gattii Complex Infections
}

\author{
James H. Diaz, MD, DrPH ${ }^{1,2}$ \\ ${ }^{1}$ Environmental and Occupational Health Sciences, School of Public Health, Louisiana State University Health Sciences Center (LSUHSC), New Orleans, \\ LA; ${ }^{2}$ School of Medicine, Louisiana State University Health Sciences Center (LSUHSC), New Orleans, LA
}

\begin{abstract}
Cryptococcus neoformans, a soil-dwelling fungus found worldwide, can cause cryptococcosis, an opportunistic fungal infection of the lungs and central nervous system. One former member of the $C$ neoformans complex, Cryptococcus gattii, has caused meningitis in immunosuppressed and immunocompetent persons in endemic regions in Africa and Asia. Between 1999 and 2004, C gattii caused outbreaks of human cryptococcosis in unexpected, nonendemic, nontropical regions on Vancouver Island, Canada, and throughout the US Pacific Northwest and California. C gattii was recognized as an emerging species with several genotypes and a unique environmental relationship with trees that are often encountered in the wilderness and in landscaped parks. Because $C$ gattii infections have a high case-fatality rate, wilderness medicine clinicians should be aware of this emerging pathogen, its disease ecology and risk factors, its expanding geographic distribution in North America, and its ability to cause fatal disease in both immunosuppressed and immunocompetent persons.
\end{abstract}

Keywords: cryptococcosis, cryptococcomas

\section{Introduction}

The Cryptococcus neoformans complex species are sporeforming, soil-dwelling fungi distributed worldwide. C neoformans causes opportunistic fungal infections of the lungs and central nervous system (CNS) in immunosuppressed persons with cancer, diabetes, human immunodeficiency virus (HIV) infection, and acquired immunodeficiency syndrome (AIDS). Other species in the $C$ neoformans complex, such as Cryptococcus albidus and Cryptococcus laurentii, also cause meningitis in patients with compromised immunity in the tropics. Another tropical species, Cryptococcus gattii, causes meningitis in both immunosuppressed and immunocompetent persons in hyperendemic regions of Africa, India, South America, Northern Australia, and Papua New Guinea.

Corresponding author: James H. Diaz, MD, DrPH, FASTMH, Louisiana State University Health Sciences Center (LSUHSC) in New Orleans, Office, 2020 Gravier Street, Third Floor, New Orleans, LA 70112; e-mail: jdiaz@1suhsc.edu.

Submitted for publication January 2019.

Accepted for publication October 2019.
The disease ecology, microbiology, and epidemiology of $C$ neoformans complex cryptococcosis changed in 1999 when $C$ gattii caused an outbreak of human and animal cryptococcosis in Canada. This outbreak occurred on Vancouver Island, British Columbia, an unexpected, nonendemic, and nontropical region for a $C$ gattii outbreak. ${ }^{1,2}$

Today, $C$ gattii is classified as a new fungal species complex with 5 genotypes. All genotypes are capable of causing cryptococcosis in both immunocompromised and immunocompetent persons. ${ }^{3,4}$ The objectives of this review are 1) to describe the new genotypes of $C$ gattii, their geographic distributions, and the immunocompetency status of their human hosts; 2) to identify any environmental and other risk factors for $C$ gattii complex infections; 3 ) to describe the clinical presentation of $C$ gattii complex infections; and 4) to recommend management and prevention strategies.

Wilderness medicine clinicians should be aware of this emerging pathogen complex; its expanding geographic distribution range, especially in North America; its unique association with commonly encountered tree species; and 
Table 1. Scientific articles reviewed, referenced, and stratified by types

\begin{tabular}{lllllll}
\hline & $\begin{array}{l}\text { Review } \\
\text { articles }\end{array}$ & $\begin{array}{l}\text { Descriptive } \\
\text { epidemiological } \\
\text { investigations }\end{array}$ & $\begin{array}{l}\text { Molecular epidemiological } \\
\text { investigations }(C \text { gattii } \\
\text { complex genotyping } \\
\text { by PCR })\end{array}$ & $\begin{array}{l}\text { Outbreak } \\
\text { investigations }\end{array}$ & $\begin{array}{l}\text { Mycological } \\
\text { reports }\end{array}$ & $\begin{array}{l}\text { Case reports } \\
\text { and case } \\
\text { series }\end{array}$ \\
\hline $\begin{array}{c}\text { Articles reviewed } \\
(\mathrm{n}=66)\end{array}$ & 16 & 13 & 9 & 10 & 11 & 7 \\
$\begin{array}{c}\text { Articles referenced } \\
(\mathrm{n}=48)\end{array}$ & 11 & 12 & 5 & 10 & 5 & 6 \\
\hline
\end{tabular}

PCR, polymerase chain reaction assay.

a Articles not reviewed: clinical-pathological case conference reports and opinion-editorial articles.

its ability to cause devastating disease in the lungs and CNS in both immunocompromised and immunocompetent patients.

\section{Methods}

Internet search engines including PubMed, Medline, Ovid, Google, Google Scholar, and Cochrane were queried with the keywords as subject headings. The study period was defined as 1970 to 2018. In addition to Cryptococcus gattii complex, other keywords included Cryptococcus, cryptococcosis, and cryptococcomas. The articles selected as meeting these objectives included review articles, case reports and series, descriptive epidemiological investigations, molecular epidemiological investigations, outbreak investigations, and mycological reports (Table 1). Articles excluded from review included clinical-pathological conference reports and opinion-editorial articles.

\section{Results \\ THE TAXONOMY OF THE CRYPTOCOCCUS GATTII SPECIES COMPLEX}

Table 2 describes the $C$ gattii species by their variety Gattii (VG) genotypes and subtypes, global distributions, and the

Table 2. Cryptococcus gattii species complex isolates, geographic distributions, and the immunocompetency status of infected human hosts

\begin{tabular}{|c|c|c|c|}
\hline $\begin{array}{l}\text { Subspecies in } \\
\text { the } C \text { gattii } \\
\text { species } \\
\text { complex }\end{array}$ & $\begin{array}{l}\text { Assigned genotypes (and } \\
\text { subtypes) }\end{array}$ & $\begin{array}{l}\text { Geographic distributions of clinical } \\
\text { specimens }^{\text {a }}\end{array}$ & $\begin{array}{l}\text { Immunocompetency status of } \\
\text { infected human hosts }\end{array}$ \\
\hline $\begin{array}{l}\text { Cryptococcus } \\
\text { gattii sensu } \\
\text { stricto }\end{array}$ & Var. Gattii VGI & $\begin{array}{l}\text { Most widely distributed: Australia, North } \\
\text { America (Pacific Northwest, }{ }^{\text {b }} \text { US West } \\
\text { Coast, Southeast United States), Europe } \\
\text { (France, Netherlands), China, Papua New } \\
\text { Guinea }\end{array}$ & $\begin{array}{l}\text { Immunocompetent and } \\
\text { non-AIDS immunocompromised } \\
\text { (by diabetes, cancer, or steroid } \\
\text { therapy) }\end{array}$ \\
\hline $\begin{array}{l}\text { Cryptococcus } \\
\text { deuterogattii }\end{array}$ & VGII subtypes a, b, and c. & $\begin{array}{l}\text { Next most widely distributed: Australia, } \\
\text { India, China, Korea, South America (Brazil, } \\
\text { French Guyana), North America (Pacific } \\
\text { Northwest), France, Africa (Senegal) }\end{array}$ & $\begin{array}{l}\text { Immunocompetent and } \\
\text { non-AIDS immunocompromised } \\
\text { (by diabetes, cancer, or steroid } \\
\text { therapy) }\end{array}$ \\
\hline $\begin{array}{l}\text { Cryptococcus } \\
\text { bacillisporus }\end{array}$ & VGIII & $\begin{array}{l}\text { Restricted distribution: Australia, Mexico, } \\
\text { South America (Brazil, Colombia), North } \\
\text { America (Pacific Northwest), Papua New } \\
\text { Guinea }\end{array}$ & $\begin{array}{l}\text { AIDS immunocompromised }> \\
\text { immunocompetent }\end{array}$ \\
\hline $\begin{array}{l}\text { Cryptococcus } \\
\text { tetragattii }\end{array}$ & VGIV & $\begin{array}{l}\text { Most restricted distribution: Africa } \\
\text { (Botswana, Malawi, South Africa), India }\end{array}$ & $\begin{array}{l}\text { AIDS immunocompromised > } \\
\text { immunocompetent }\end{array}$ \\
\hline $\begin{array}{l}\text { Cryptococcus } \\
\text { decagattii }\end{array}$ & $\begin{array}{l}\text { Not genotyped as VG5 yet; } \\
\text { only } 5 \text { organisms isolated } \\
\text { and identified at present }\end{array}$ & Distribution unknown & Unknown \\
\hline
\end{tabular}

\footnotetext{
AIDS, acquired immunodeficiency syndrome.

${ }^{\text {a }}$ Does not include environmental or veterinary isolates.

b The Pacific Northwest includes Vancouver Island and British Columbia in Canada and the states of Washington and Oregon.
} 


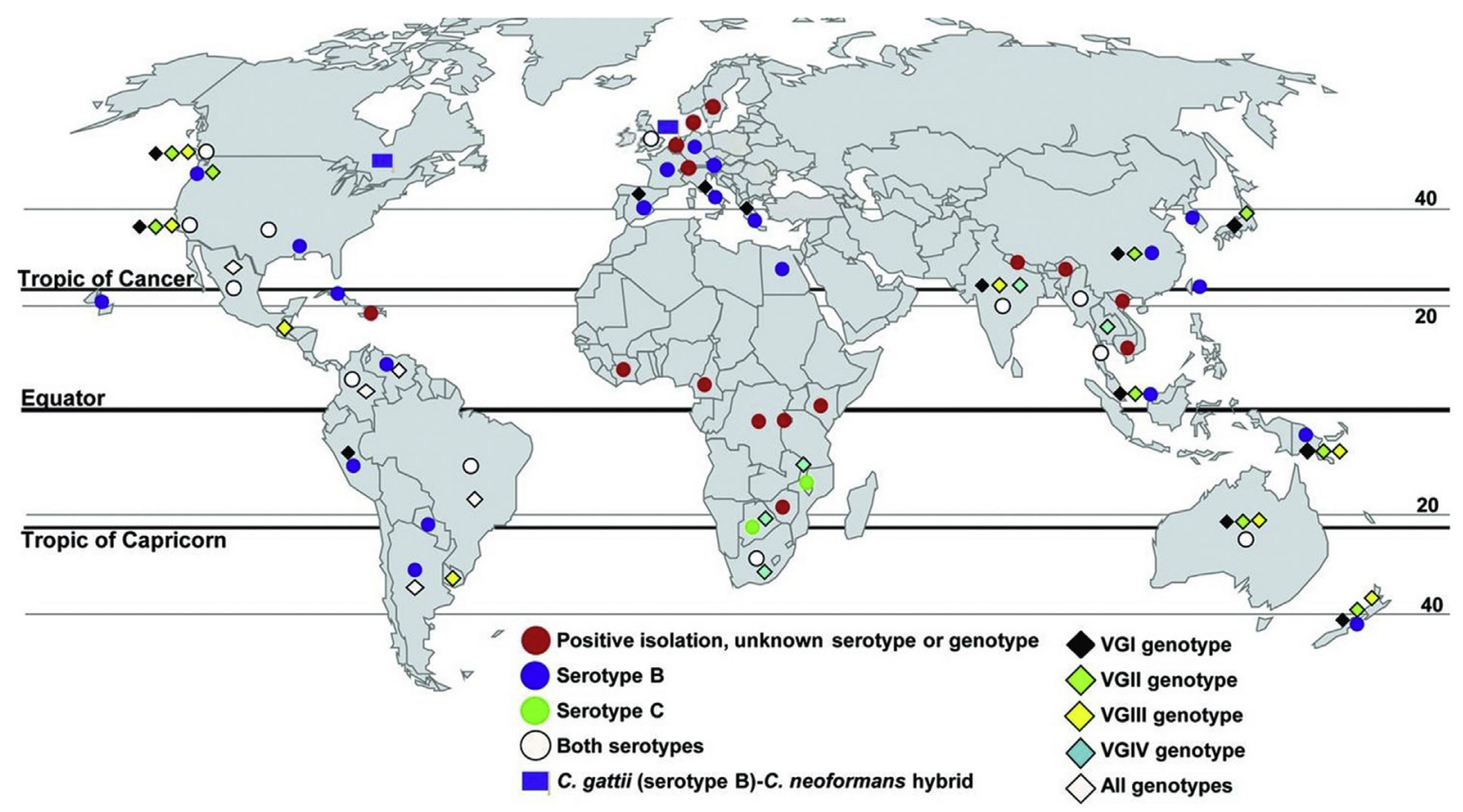

Figure 1. Worldwide isolates of Cryptococcus gattii serotypes and genotypes from clinical, veterinary, and environmental sources. Source: Springer and Chaturvedi. ${ }^{5}$ Public domain, no copyright permission required. Available at: https://wwwnc.cdc.gov/eid/article/.

immunocompetency status of infected patients. Figure 1 depicts the worldwide isolates of $C$ gattii serotypes and genotypes from clinical, veterinary, and environmental sources. $^{5}$

\section{THE DISEASE ECOLOGY OF C GATTI COMPLEX INFECTIONS}

Unlike C neoformans, which is found in soils contaminated with wild and pet bird droppings, especially pigeon droppings, $C$ gattii mold forms prefer tree trunks and in soil debris near specific trees that are often found in the wild or used for municipal landscaping. ${ }^{6}$ Table 3 presents the global distribution of environmental isolates of $C$ gattii and their unique ecological niches in specific trees. ${ }^{7-21}$

\section{THE EPIDEMIOLOGY OF CRYPTOCOCCUS GATTII COMPLEX INFECTIONS}

Among the $C$ gattii genotypes, VGI is most commonly isolated worldwide in environmental samples and cryptococcal infections in animals and humans. ${ }^{19}$ The highest global incidence rates of $C$ gattii infections are reported in Northern Australia and Papua New Guinea and are usually caused by subtypes of VGII. ${ }^{19}$ VGI and VGII genotypes primarily infect immunocompetent or non-AIDS immunocompromised patients worldwide. ${ }^{19}$
By 2004, C gattii outbreaks had spread from Vancouver to the US Pacific Northwest and California. ${ }^{20-25}$ Unlike $C$ neoformans infections, the North American $C$ gattii cases were evenly distributed among immunocompromised and immunocompetent patients. ${ }^{25}$ Recently, the US distribution range of $C$ gattii infections expanded into the southeastern United States, with cases described in North Carolina and Georgia. ${ }^{26,27}$ Table 4 describes regional outbreaks of $C$ gattii complex infections in North America over the reporting period of 1997 to 2018. ${ }^{1,25-27}$

Patients with $C$ gattii species complex infections are not infectious, and cryptococcosis is not transmissible from human to human or from animal to human. ${ }^{25}$ Both humans and animals can be infected by any of the $C$ gattii genotypes by deeply inhaling dried, environmentally stable basidiospores through the upper airway and into the lungs. ${ }^{28}$ Pulmonary infections occur in 50 to $60 \%$ of patients and range from asymptomatic to mild influenza-like illnesses. Once exposed to body temperature, the spores develop thick outer capsules that resist immune attack, multiply by budding, and travel via the bloodstream on their own or within phagocytes or white blood cells to infect other organ systems, typically the CNS. Experts attribute the organism's ability to resist immune attack and cause disease in healthy, immunocompetent subjects to these specialized intracellular defense mechanisms. ${ }^{28,29}$ 
Table 3. Global distribution of environmental isolates of Cryptococcus gattii genotypes and their ecological niches in specific trees ${ }^{7-21}$

\begin{tabular}{|c|c|c|c|c|}
\hline Country & Genotypes & $\begin{array}{l}\text { Tree species (scientific } \\
\text { names) }\end{array}$ & $\begin{array}{l}\text { Tree species (common } \\
\text { names) }\end{array}$ & $\begin{array}{l}\text { Reference } \\
\text { numbers }\end{array}$ \\
\hline India & $\begin{array}{l}\text { Cryptococcus gattii } \\
\text { sensu srticto } \\
\text { VGI }\end{array}$ & $\begin{array}{l}\text { Azadirachta indica } \\
\text { Cassia fistula } \\
\text { Cassia marginata } \\
\text { Castanopsis } \\
\text { argyrophylla } \\
\text { Ficus religiosa } \\
\text { Eucalyptus } \\
\text { camaldulensis } \\
\text { Eucalyptus tereticornis } \\
\text { Mimusops elengi } \\
\text { Manikara hexandra } \\
\text { Polyalthia longifolia } \\
\text { Syzygium cumini }\end{array}$ & $\begin{array}{l}\text { Indian lilac tree (nimtree) } \\
\text { Indian laburnum tree } \\
\text { Red shower tree } \\
\text { Chinkapin tree } \\
\text { Sacred fig tree } \\
\text { River red gum tree } \\
\text { Forest red gum tree } \\
\text { Spanish cherry tree } \\
\text { Ceylon wood tree } \\
\text { False Ashoka tree } \\
\text { Java plum tree }\end{array}$ & $7-14$ \\
\hline Thailand & $\begin{array}{l}\text { Cryptococcus gattii } \\
\text { sensu lato } \\
\text { VGI }\end{array}$ & $\begin{array}{l}\text { Castanopsis } \\
\text { argyrophylla }\end{array}$ & Chinkapin tree & 15 \\
\hline Tunisia & $\begin{array}{l}\text { Cryptococcus gattii } \\
\text { sensu lato } \\
\text { VGI }\end{array}$ & Prunus dulcis & Almond tree & 16 \\
\hline Australia & $\begin{array}{l}\text { Cryptococcus bacillisporus } \\
\text { VGIII }\end{array}$ & $\begin{array}{l}\text { Eucalyptus } \\
\text { camaldulensis }\end{array}$ & River red gum tree & 17 \\
\hline $\begin{array}{l}\text { United States } \\
\text { (Southern California) }\end{array}$ & $\begin{array}{l}\text { Cryptococcus gattii sensu } \\
\text { lato } \\
\text { VGI } \\
\text { Cryptococcus bacillisporus } \\
\text { VGIII }\end{array}$ & $\begin{array}{l}\text { Pinus canariensis } \\
\text { Liquidambar styraciflua } \\
\text { Metrosideros excelsa }\end{array}$ & $\begin{array}{l}\text { Canary Island pine tree } \\
\text { American sweet gum tree } \\
\text { Pohutukawa tree }\end{array}$ & 18 \\
\hline $\begin{array}{l}\text { Canada (British Columbia, } \\
\text { Vancouver Island) and } \\
\text { United States, Pacific } \\
\text { Northwest }\end{array}$ & $\begin{array}{l}\text { Cryptococcus deuterogattii } \\
\text { VGII }\end{array}$ & $\begin{array}{l}\text { Pseudotsuga menziesii } \\
\text { Tsuga heterophylla }\end{array}$ & $\begin{array}{l}\text { Douglas fir } \\
\text { Western hemlock }\end{array}$ & 21 \\
\hline
\end{tabular}

Table 4. Regional outbreaks of Cryptococcus gattii infections, North America, 1997-2018

\begin{tabular}{|c|c|c|c|c|}
\hline Dates & Locations & No. of cases & $\begin{array}{l}\text { Causative } \\
\text { genotypes }\end{array}$ & Reference numbers \\
\hline Jun 1, 1997-Dec 31, 2002 & $\begin{array}{l}\text { Vancouver Island, } \\
\text { British Columbia, Canada }\end{array}$ & $\begin{array}{l}26 \text { (15 HIV+ and } \\
11 \text { HIV-) }\end{array}$ & VGII & 1 \\
\hline \multirow[t]{4}{*}{$\begin{array}{r}\text { Jan 1, 2004-Jul 1, } 2010 \\
\text { (US Pacific Northwest) }\end{array}$} & Oregon & 43 (12 deaths) & $\begin{array}{l}\text { VG IIa, } \\
\text { VGIIb, } \\
\text { VGIIc, } \\
\text { VGIII }\end{array}$ & $\begin{array}{l}25 \\
\text { Note: Most patients } \\
(57 \%) \text { had clinical } \\
\text { evidence of }\end{array}$ \\
\hline & Washington & 15 (3 deaths) & VGIIa & pneumonia \\
\hline & California & 1 & VGII & \\
\hline & Idaho & 1 & VGII & \\
\hline 2007 & $\begin{array}{l}\text { North Carolina (first case } \\
\text { reported in the southeast US) }\end{array}$ & $\begin{array}{l}1 \text { (HIV-, subcutaneous } \\
\text { cryptococcoma right } \\
\text { thigh, } 2 \text { intracerebral } \\
\text { cryptococcomas) }\end{array}$ & VG1 & 26 \\
\hline 2018 & Southwestern Georgia, US & $3($ All HIV +) & Not speciated & 27 \\
\hline
\end{tabular}

HIV, human immunodeficiency virus. 
Fatal disseminated mycoses can occur in immunocompetent or immunosuppressed patients. ${ }^{30-32}$ The incubation period for $C$ gattii species complex infections is not well established, with an average of 6 mo and a range of a few months to up to $3 \mathrm{y} .{ }^{30-32}$ In an epidemiological analysis of 218 cases in British Columbia, Canada, over the reporting period of 1999 to 2007, the incubation period was 6 to 7 mo with a range of 2 to 13 mo. ${ }^{32}$ The mean age of patients was $59 \mathrm{y} .{ }^{32}$ The age-specific incidence rate was highest among patients aged 70 to $79 \mathrm{y} .{ }^{32}$ Only $38 \%$ of patients in the British Columbia series had an immunosuppressive condition. ${ }^{32}$ The authors attributed the increasing incidence of cases during the early years (1999-2001) of the Canadian outbreak to a possible combination of several factors, including 1) increased awareness of the disease, 2) increased reporting of the disease, 3 ) a true increase in disease incidence owing to greater airborne spore concentrations over time, and 4) gradual cumulative infections in spore-exposed persons over time. ${ }^{32}$

Although the case fatality rate in the British Columbia outbreak caused by VGII was $9 \%$, it ranged from 13 to $33 \%$ in outbreaks in Australia and Papua New Guinea and in the US Pacific Northwest. ${ }^{32-36}$ Experts attributed this wide range in mortality rates among these outbreaks to differences in patient immunocompetency status, virulence of the $C$ gattii genotype, antifungal treatment strategies, and length of follow-up. ${ }^{32-37}$

Residency and travel in endemic areas and exposure to infected tree are the most significant risk factors for contracting $C$ gattii infections (Table 3) ${ }^{7-21}$ In Australia and New Zealand, additional risk factors include male sex and Australian aborigine ethnicity. ${ }^{35}$ In British Columbia, additional risk factors include smoking, pre-existing lung disease, age $\geq 50 \mathrm{y}$, and immunosuppression from corticosteroid therapy, cancer chemotherapy, or HIV/ AIDS. ${ }^{33}$ Specific recreational and occupational risk factors for $C$ gattii complex infections have not been described other than tree exposures, which would be increased during harvesting of infected trees for firewood or construction and during tree trimming and tree trunk repairs. Outbreaks of histoplasmosis have been reported in persons exposed to infectious aerosols containing heat-stable spores generated by bonfires and burn pits containing Histoplasma capsulatum-infected bamboo. ${ }^{38,39}$

Mold forms of $C$ gattii prefer to grow within and underneath moist bark, in tree hollows, and in hollows and scars in tree trunks. Hiking or camping in areas with large numbers of infected trees and breaking off or cutting diseased limbs for walking sticks, firewood, or tent supports and stakes could potentially put persons at even greater risk of inhaling infective basidiospores. Even short-term exposure during nature walking, hiking, or camping in endemic areas or exposure to infected trees or tree trunks has resulted in symptomatic cryptococcosis, especially in the immunocompromised (Table 3) ${ }^{7-18}$ The minimum infectious dose of inhaled infective basidiospores is unknown.

$C$ gattii infections occur more often in immunocompetent persons than $C$ neoformans infections, which typically target persons with HIV/AIDS. In addition to exposure to several species of trees, recent evidence has identified new risk factors for contracting $C$ gattii infections in potentially immunocompromised persons, including diabetes and end-stage liver or renal disease and a syndrome characterized by the production of autoantibodies against granulocyte-macrophage stimulating factor leading to macrophage dysfunction. $27,37-41$

\section{THE CLINICAL MANIFESTATIONS OF CRYPTOCOCCUS GATTII COMPLEX INFECTIONS}

The initial phase of $C$ gattii infection is marked by 2 wk of fever, night sweats, malaise, and coughing resembling an influenza-like illness without myalgia. ${ }^{30-32}$

Cryptococcal skin lesions usually occur on the face and neck more often in immunosuppressed patients in endemic areas than in immunocompetent persons. Only 6 cases of cutaneous cryptococcosis in immunocompetent persons have been reported to date. ${ }^{41}$ In 2006, Dora et al reported a case of cutaneous cryptococcosis in an immunocompetent patient exposure to Eucalyptus sp tropical trees in an endemic area. ${ }^{41}$ Skin lesions take several morphologies, including acneiform lesions, cellulitis, papules, plaques, pustules, ulcers, and subcutaneous focal masses, known as cryptococcomas. $^{41}$

Immunocompetent patients typically experience milder illness with initial influenza-like symptoms followed by chronic cough for weeks to months. Patients immunocompromised by HIV infection, diabetes, and liver or renal failure experience more severe symptoms, such as pneumonia, meningitis, meningoencephalitis, and focal mass cryptococcomas in the lungs, skin, brain, or other organs (Figure 2). ${ }^{27}$

\section{THE DIFFERENTIAL DIAGNOSIS OF CRYPTOCOCCUS GATTII COMPLEX INFECTIONS}

The differential diagnosis of Cryptococcus gattii pneumonia includes influenza, atypical pneumonia, community acquired pneumonia, and tuberculosis. Severe cryptococcal pneumonia with solid and cavitary cryptococcomas may resemble lung abscesses, echinococcal cysts, paragonimiasis, or malignancies such as high-grade lymphomas and small cell cancers. In addition to tuberculosis, other infectious or granulomatous processes such as sarcoidosis, mycobacterial pneumonias, and endocarditis with septic pulmonary emboli may also mimic $C$ gattii infection. The 


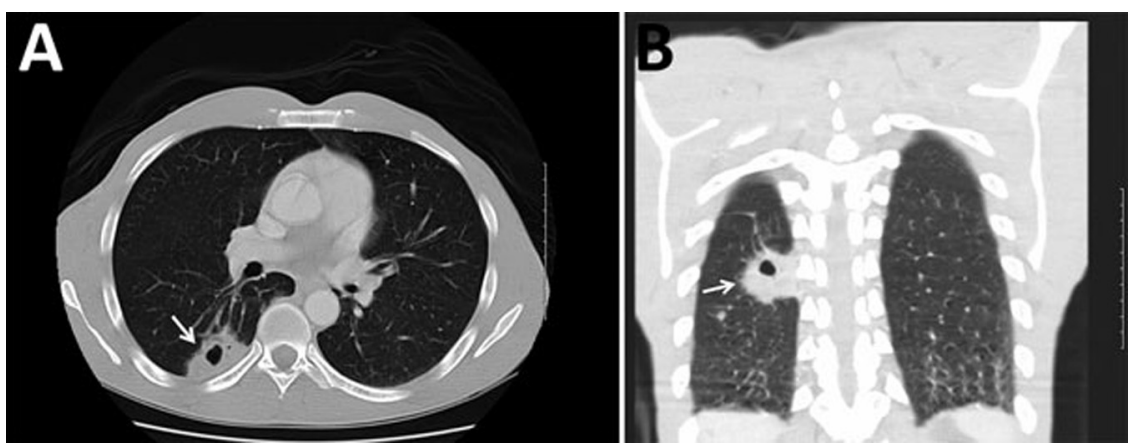

Figure 2. Computed tomography images of the chest of a 47-y-old male with Cryptococcus gattii complex infection, southeastern United States. Transverse (A) and frontal (B) views without intravenous contrast showed a mass $(4.0 \mathrm{~cm} \times 2.5 \mathrm{~cm})$ with a central cavitation (arrows) in the posterior right lower lobe consistent with a pulmonary cryptococcoma. Source: Bruner et al. ${ }^{27}$ Public domain, no copyright permission required. Available at: https://wwwnc.cdc.gov/eid/article/24/11/18-0787-f1.

differential diagnosis of cryptococcal meningitis and meningoencephalitis includes other brain infections, such as West Nile virus neuroinvasive disease and free-living amebic infections of the brain caused by Naegleria fowleri, Balamuthia mandrillaris, and Sappinia pedata. ${ }^{27,42,43}$

\section{THE LABORATORY DIAGNOSIS OF CRYPTOCOCCUS GATTII COMPLEX INFECTIONS}

Laboratory confirmation of Cryptococcus gattii complex infections may require several steps, including microscopic, microbiological, immunological, and molecular laboratory methods, to differentiate $C$ neoformans complex from $C$ gattii complex infections and to speciate the genotypes of $C$ gattii. ${ }^{44}$ These diagnostic steps are necessary not only for identifying the specific causative pathogen for epidemiological purposes, but also for selection of the most effective antifungal medications for prolonged therapy. ${ }^{44}$

Microscopic examination of specially stained (eg, Grocott's methanamine silver stain, India ink stain, Field stain, and mucicarmine stain) histologic slides prepared from sputum or bronchoalveolar lavage specimens, serum or cerebrospinal fluid specimens, or skin, lung, and brain biopsies may demonstrate characteristic budding yeast forms with polysaccharide capsules but will not differentiate $C$ neoformans from $C$ gattii. ${ }^{44}$ Similarly, cryptococcal antigen testing on serum or cerebrospinal fluid may serve as a highly sensitive preliminary serological test for cryptococcal infection but will not differentiate $C$ neoformans from $C$ gattii infection or distinguish among different genotypes of Cryptococcus, as needed to guide precise antifungal therapy. ${ }^{44}$ Only specialized fungal cultures or DNA analyses by polymerase chain reaction assays will permit differentiation among the 5 C gattii genotypes. ${ }^{44}$

\section{THE TREATMENT OF CRYPTOCOCCUS GATTII COMPLEX INFECTIONS}

The treatment of cryptococcal pneumonia or meningoencephalitis requires both initial induction or drug-loading therapy with intravenous liposomal amphotericin B and oral fluocytosine followed by subsequent consolidation or long-term, chronic drug therapy with oral antifungals, either fluconazole or voriconazole, for a minimum of 6 mo. ${ }^{45-48}$ Asymptomatic infections or mild-to-moderate pulmonary infections without CNS involvement may be treated with chronic consolidation therapy alone with oral fluconazole or voriconazole for a period of 6 to 8 mo. $^{44}$

Patients who are infected with $C$ gattii complex may require longer induction courses of intravenous amphotericin B-based therapy compared with patients infected with C neoformans complex. ${ }^{45-48}$ In addition, there may be a difference in pathogen susceptibilities to the oral azoles that suggests the use of voriconazole or flucytosine instead of fluconazole for prolonged oral consolidation therapy of $C$ gattii complex cases compared to $C$ neoformans cases. ${ }^{49}$ Because the type, dose, and duration of antifungal induction and consolidation therapy may differ for certain high-risk groups, such as pregnant or HIV-infected patients and organ transplant recipients, clinicians are encouraged to consult the latest treatment recommendations from the Infectious Diseases Society of America's Clinical Practice Guidelines for the Management of Cryptococcal Disease and other expert sources and guidelines. ${ }^{48}$

In addition to intravenous antifungal induction therapy for cryptococcal meningoencephalitis, intravenous dexamethasone may be indicated for the management of recurrent headaches from cerebral edema. ${ }^{27}$ Surgical management may also be required to relieve hydrocephalus with ventriculoperitoneal shunts or to remove large cryptococcomas in the lungs or brain (Figure 2). ${ }^{27}$ 


\section{THE PREVENTION OF CRYPTOCOCCUS GATTII COMPLEX INFECTIONS}

Other than recognition of the human and environmental risk factors for $C$ gattii complex infections, there are no effective primary prevention strategies for cryptococcosis, including chemoprophylaxis. In addition, the absence of objective scientific data to support preventive strategies for cryptococcosis does not provide a basis for strong recommendations for prevention. Nevertheless, arborists and campers intentionally pruning or cutting diseased tree limbs for disposal or for firewood may consider wearing an N95 facemask that covers the nose and mouth to prevent inhalation of aerosolized, infective spores. Because histoplasmosis cases have now been linked to the inhalation of heat-stable aerosolized spores in smoke, dead tree limbs covered with obvious mold should not be burned because such firewood could create infectious aerosols. ${ }^{38,39}$

There are no commercially available tests to detect $C$ gattii in soil or in trees. The testing of environmental samples is performed only for research or epidemiological studies to determine endemicity and to confirm regional associations with specific tree species.

\section{Conclusions}

Human $C$ gattii infection, which was formerly limited to tropical regions worldwide but re-emerged in Canada in 1999, has now spread regionally in the United States, causing over 200 infections in North America. Since 2004, the pathogen has become established in the Canadian and US Pacific Northwest, Southern California, and the Southeastern United States. Because the infection has a high casefatality rate, early diagnosis and prolonged antifungal therapy in compliance with updated guidelines are recommended. Wilderness medicine clinicians should be aware of this emerging pathogen complex; its expanding geographic distribution range, especially in North America; its unique association with certain tree species; and its ability to cause devastating disease in the lungs and CNS in both immunocompromised and immunocompetent patients.

Financial/Material Support: Provided by departmental and institutional sources.

Disclosures: None.

\section{References}

1. Hoang LM, Maguire JA, Doyle P, Fyfe M, Roscoe DL. Cryptococcus neoformans infections at Vancouver Hospital and Health Sciences Centre (1997-2002): epidemiology, microbiology and histopathology. J Med Microbiol. 2004;53(Pt 9): 935-40.

2. Fyfe M, MacDougall L, Romney M, Starr M, Pearce M, Mak S, et al. Cryptococcus gattii infections on Vancouver
Island, British Columbia, Canada: emergence of a tropical fungus in a temperate environment. Can Commun Dis Rep. 2008;34(6):1-12.

3. Kwon-Chung KB, Boekhout T, Fell JW, Diaz M. Proposal to conserve the name Cryptococcus gattii against C. hondurianus and C. bacillisporus (Basidiomycota, Hymenomycetes, Tremellomycetidae). Taxon. 2002;51(4):804-6.

4. Ngamskulrungroj P, Gilgado F, Faganello J, Litvintseva AP, Leal AL, Tsui KM, et al. Genetic diversity of the Cryptococcus species complex suggests that Cryptococcus gattii deserves to have varieties. PLoS One. 2009;4(6):e5862.

5. Springer DJ, Chaturvedi V. Projecting global occurrence of Cryptococcus gattii. Emerg Infect Dis. 2010;16(1):14-20.

6. Kielstein P, Hotzel H, Schmalreck A, Khaschabi D, Glawischnig W. Occurrence of Cryptococcus spp. in excreta of pigeons and pet birds. Mycoses. 2000;43(1-2):7-15.

7. Randhawa HS, Kowshik T, Khan ZU. Decayed wood of Syzgium cumini and Ficus religiosa living trees in Delhi/New Delhi metropolitan area as natural habitat of Cryptococcus neoformans. Med Mycol. 2003;41(3):199-209.

8. Randhawa HS, Kowshik T, Preeti Sinha K, Chowdhary A, Khan ZU, Yan Z, et al. Distribution of Cryptococcus gattii and Cryptococcus neoformans in decayed trunk wood of Syzygium cumini trees in north-western India. Med Mycol. 2006;44(7):623-30.

9. Khan ZU, Randhawa HS, Kowshik T, Chowdhary A, Chandy R. Antifungal susceptibility of Cryptococcus neoformans and Cryptococcus gattii isolates from decayed wood of trunk hollows of Ficus religiosa and Syzygium cumini trees in north-western India. J Antimicrob Chemother. 2007;60(2): 312-6.

10. Randhawa HS, Kowshik T, Chowdhary A, Preeti Sinha K, Khan ZU, Sun S, et al. The expanding host tree species spectrum of Cryptococcus gattii and Cryptococcus neoformans and their isolations from surrounding soil in India. Med Mycol. 2008;46(8):823-33.

11. Girish Kumar CP, Prabu D, Mitani H, Mikami Y, Menon T. Environmental isolation of Cryptococcus neoformans and Cryptococcus gattii from living trees in Guindy National Park, Chennai, South India. Mycoses. 2010;53(3):262-4.

12. Randhawa HS, Kowshik T, Chowdhary A, Prakash A, Khan ZU, Xu J. Seasonal variations in the prevalence of Cryptococcus neoformans var. grubii and Cryptococcus gattii in decayed wood inside trunk hollows of diverse tree species in northwestern India: a retrospective study. Med Mycol. 2011;49(3):320-3.

13. Chowdhary A, Prakash A, Randhawa HS, Kathuria S, Hagen F, Klaassen CH, et al. First environmental isolation of Cryptococcus gattii, genotype AFLP5, from India and a global review: Cryptococcus gattii, genotype AFLP5, from India. Mycoses. 2013;56(3):222-8.

14. Gutch RS, Nawange SR, Singh SM, Yadu R, Tiwari A, Gumasta R, et al. Antifungal susceptibility of clinical and environmental Cryptococcus neoformans and Cryptococcus gattii isolates in Jabalpur, a city of Madhya Pradesh in Central India. Braz, J Microbiol. 2015;46(4):1125-33. 
15. Khayhan K, Hagen F, Norkaew T, Puengchan T, Boekhout T, Sriburee P. Isolation of Cryptococcus gattii from a Castanopsis argyrophylla tree hollow (Mai-Kaw), Chiang Mai, Thailand. Mycopathologica. 2017;182(3-4):365-70.

16. Mseddi F, Sellami A, Jarboui MA, Sellami H, Makni F, Ayadi A. First isolation of Cryptococcus neoformans and Cryptococcus gattii in Tunisia and review of published studies on environmental isolations in Africa. Mycopathologica. 2011;171(5):355-60.

17. Jenney A, Pandithage K, Fisher DA, Currie BJ. Cryptococcus infection in tropical Australia. J Clin Microbiol. 2004;42(8): 3865-8.

18. Springer DJ, Billmyre RB, Filler EE, Voelz K, Pursall R, Mieczkowski PA, et al. Cryptococcus gattii VGII isolates causing infections in HIV/AIDS patients in Southern California: identification of the local environmental sources as arboreal. PLoS Pathog. 2014;10(8):e1004285.

19. Springer DJ, Phadke S, Billmyre B, Heitman J. Cryptococcus gattii, no longer an accidental pathogen? Curr Fungal Infect Rep. 2012;6(4):245-56.

20. Upton A, Fraser JA, Kidd SE, Bretz C, Bartlett KE, Heitman J, et al. First contemporary case of human infection with Cryptococcus gattii in Puget Sound: evidence for spread of the Vancouver Island outbreak. J Clin Microbiol. 2007:45(9):3086-8.

21. MacDougall L, Kidd SE, Galanis E, Mak S, Leslie MJ, Cieslak PR, et al. Spread of Cryptococcus gattii in British Columbia, Canada, and detection in the Pacific Northwest, USA. Emerg Infect Dis. 2007;13(1):42-50.

22. Datta K, Bartlett KH, Baer R, Byrnes E, Galanis E, Heitman J, et al. Spread of Cryptococcus gattii into the Pacific Northwest Region of the United States. Emerg Infect Dis. 2009;15(8): 1185-91.

23. Byrnes 3rd EJ, Bildfell RJ, Frank SA, Mitchell TG, Marr KA, Heitman J. Molecular evidence that the range of the Vancouver Island outbreak of Cryptococcus gattii infection has expanded into the Pacific Northwest in the United States. J Infect Dis. 2009;199(7):1081-6.

24. Dixit A, Carroll SF, Qureshi ST. Cryptococcus gattii: an emerging cause of fungal disease in North America. Interdiscip Perspect Infect Dis. 2009;2009:840452.

25. Emergence of Cryptococcus gattii-Pacific Northwest, 2004-2010. MMWR Morb Mortal Wkly Rep. 2010;59(28): 865-8.

26. Byrnes 3rd EJ, Li W, Lewit Y, Perfect JR, Carter DA, Cox GM, et al. First reported case of Cryptococcus gattii in the Southeastern USA: implications for travel-associated acquisition of an emerging pathogen. PloS One. 2009;4(6): e5851.

27. Bruner KT, Franco-Paredes C, Henao-Martinez A, Steele GM, Chastain DB. Cryptococcus gattii complex infections in HIV-infected patients, southeastern United States. Emerg Infect Dis. 2018;24(11):1998-2002.

28. Walraven CJ, Gerstein W, Hardison SE, Wormley F, Lockhart SR, Harris JR, et al. Fatal disseminated Cryptococcus gattii infection in New Mexico. PloS One. 2011;6(12): e28625.
29. Ma H, Hagan F, Stekel DJ, Johnston SA, Sionov E, Falk R, et al. The fungal outbreak on Vancouver Island is characterized by enhanced intracellular parasitism driven by mitochondrial regulation. Proc Nat Acad Sci USA. 2009;106(31): 12980-5.

30. Harris JR, Lockhart SR, Debess E, Marsden-Haug N, Goldoft M, Wohrle R, et al. Cryptococcus gattii in the United States: clinical aspects of infection with an emerging pathogen. Clin Infect Dis. 2011;53(12):1188-95.

31. Chen SC, Slavin MA, Heath CH, Playford EG, Byth K, Marriott D, et al. Clinical manifestations of Cryptococcus gattii infection: determinants of neurologic sequelae and death. Clin Infect Dis. 2012;55(6):789-98.

32. Galanis E, MacDougall L, Kidd S, Morshed M. Epidemiology of Cryptococcus gattii, British Colombia, Canada, 1999-2007. Emerg Infect Dis. 2010;16(2):251-7.

33. MacDougall L, Fyfe M, Romney M, Starr M, Galanis E. Risk factors for Cryptococcus gattii infection, British Columbia, Canada. Emerg Infect Dis. 2011;17(2):193-9.

34. Lalloo D, Fisher D, Naraqi S, Laurenson I, Temu P, Sinha A, et al. Cryptococcal meningitis (C. neoformans var. gattii) leading to blindness in previously health Melanesian adults in Papua New Guinea. Q J Med. 1994;87(6):343-9.

35. Chen S, Sorrell T, Nimmo G, Speed B, Currie B, Ellis D, et al. Epidemiology and host- and variety-dependent characteristics of infection due to Cryptococcus neoformans in Australia and New Zealand. Australasian Cryptococcal Study Group. Clin Infect Dis. 2000;31(2):499-508.

36. Carriconde F, Gilgado F, Arthur I, Ellis D, Malik R, van der Wiele N, et al. Clonality and alpha-a-recombination in the Australian Cryptococcus gattii VGII population-an emerging outbreak in Australia. PLoS One. 2011;6(2):e16936.

37. Brouwer AE, Siddiqui AA, Kester MI, Sigaloff KC, Rajanuwong A, Wannapasni S, et al. Immune dysfunction in HIV-seronegative, Cryptococcus gattii meningitis. $J$ Infect. 2007;54(3):e165-8.

38. Haselow DT, Safi H, Holcomb D, Smith N, Wagner KD, Bolden BB, et al. Histoplasmosis associated with a bamboo bonfire-Arkansas, October 2011. MMWR Morb Mortal Wkly Rep. 2014;63(8):165-8.

39. Storch G, Burford JG, George RB, Kaufman L, Ajello L. Acute histoplasmosis. Description of an outbreak in northern Louisiana. Chest. 1980;77(1):38-42.

40. Cheng PY, Sham A, Kronstad JW. Cryptococcus gattii isolates from the British Columbia cryptococcosis outbreak induce less protective inflammation in a murine model of infection than Cryptococcus neoformans. Infect Immun. 2009;77(10):4284-94.

41. Dora JM, Kelbert S, Deutschendorf C, Cunha VS, Aquino VR, Santos RP, et al. Cutaneous cryptococcosis due to Cryptococcus gattii in immunocompetent hosts: case report and review. Mycopathologica. 2006;161(4):235-48.

42. Diaz JH. Behavioral and recreational risk factors for freeliving amebic infections. J Travel Med. 2011;18(2):130-7.

43. Diaz JH. Emerging trends in free-living amebic infections of the brain: implications for organ transplantation. J La State Med Soc. 2013;165(6):314-8. 
44. United States Department of Health and Human Services. United States Centers for Disease Control and Prevention, Atlanta, Georgia, USA. Diagnosis and testing for $C$. gattii infection, 2015. Available at: https://www.cdc.gov/fungal/ diseases/cryptococcosis-gattii/diagnosis.html. Accessed November 11, 2019.

45. Chen SC, Korman TM, Slavin MA, Marriott D, Byth K, Bak N, et al. Antifungal therapy and management of complications of cryptococcosis due to Cryptococcus gattii. Clin Infect Dis. 2013;57(4):543-51.

46. Lockhart SR, Iqbal N, Bolden CB, DeBess EE, MarsdenHaug N, Worhle R, et al. Epidemiologic cutoff values for triazole drugs in Cryptococcus gattii: correlation of molecular type and in vitro susceptibility. Diag Microbiol Infect Dis. 2012;73(2):144-8.
47. Espinel-Ingroff A, Aller AI, Canton E, Castanon-Olivares LR, Chowdhary A, Cordoba S, et al. Cryptococcus neoformansCryptococcus gattii species complex: an international study of wild-type susceptibility endpoint distributions and epidemiological cutoff values for fluconazole, itraconazole, posoconazole, and voriconazole. Antimicrob Agents Chemother. 2012;56(11):5898-906.

48. Perfect JR, Dismukes WE, Dromer F, Goldman DL, Graybill JR, Hamill R, et al. Clinical Practice Guidelines for the Management of Cryptococcal Disease: 2010 update by the Infectious Diseases Society of America. Clin Infect Dis. 2010;50(3):291-322.

49. Trilles L, Fernandez-Torres B, Lazéra Mdos S, Wanke B, Guarro J. In vitro antifungal susceptibility of Cryptococcus gattii. J Clin Microbiol. 2004;42(10):4815-7. 